University of CaLIFornia.

Willis Linn Jepson: Botany, Flora of Western Middle California.

Columbian University, Washington, D. C.

Cabell Whitehead: Chemistry, A Study of the Tellurides : their Formation and Chemical Properties.

NEW YORK UNIVERSITY.

William Lawrence A. Dalton: Psychology, Experimental Studies in Association and Memory.

THE BEGINNINGS OF LABORATORY TEACHING IN AMERICA.

The American Association for the Advancement of Science celebrates this year its fiftieth anniversary. The epoch thus commemorated is notable in more than one way as that of a scientific awakening in this country. The foundation of the Association; the welcome given to Agassiz, whose first lectures were delivered at the Lowell Institute in 1846 ; the enthusiasm greeting the astronomical pilgrimages of $O$. M. Mitchell, to quote but a few out of many indications, show an aroused public sentiment with regard to natural science.

In no way is this movement more striking than in the effect upon scientific teaching in the colleges. For many years this had been nearly at a standstill. The methods seem to have been everywhere much the same. Instruction was by text-book and lecture. The lectures were illustrated, the illustrations of the spectacular sort. The magnitude or brilliancy of a lecture experiment was often as highly valued as its actual illustrative character. Thus the compound blowpipe and the mammoth batteries of Robert Hare were eagerly welcomed by Benjamin Silliman, with a keen appreciation of effects, and he points with a just pride to the hugeness of the electromagnet constructed for Yale College under the direction of Joseph Henry.

The Yale catalogue of 1822 announces that "The junior class attends a course of experimental natural philosophy; and the senior class the courses in chemistry, mineralogy, geology and the principles of natural philosophy."

All these courses were under the charge of Professor Silliman, and the above formula remains practically unchanged in the catalogues for upwards of twenty-five years, or until after the founding of the Scientific School. Other college catalogues, Amherst, Bowdoin, Brown, Harvard, Princeton, tell a similar story.

At Dartmouth, as at Yale, the necessity of providing for medical students required the maintenance of a somewhat high scientific standard, and a brief summary of the progress of chemical teaching at Dartmouth probably gives an idea of the best opportunities of the day.

Lectures on chemistry were given at Dartmouth before the opening of the present century, the lecturer holding the double title-varying somewhat from year to year - of professor (or lecturer) on chemistry and medicine.

In 1820 James Freeman Dana is professor of chemistry, mineralogy and the application of science to the arts ; in 1822 professor of chemistry, mineralogy, pharmacy and legal medicine. The number of departments under control of one man sufficiently indicates the paucity of the courses.

In 1825 Professor Dana published an 'Epitome of Chemical Philosophy.' This appears to be the first mention of a textbook in chemistry, though these were probably in use before. In 1833 Turner's Chemistry was used, and then successively Kane's, Fownes' and Silliman's. Through much of this period a small fee is charged students attending the chemical lectures, which are given in connection with the text-book.

In the catalogue for 1851-52 the statement is made that 'the chemical laboratory is amply furnished with apparatus and chemicals for illustration of lectures in that 
department.' The founding of the Chandler Scientific School at this period put the teaching of science on an entirely different plane.

Like conditions prevailed everywhere. The spirit of investigation showed itself actively enough in some directions, but it does not seem to have impressed itself upon the teaching, and, in fact, was not generally. connected with the colleges. As is to be expected in a new country, it expended itself mainly in exploration, in geological, botanical and ornithological collection, and the school of wandering naturalists, connected, perhaps, chiefly with Philadelphia, would furnish an interesting chapter in the history of science.

What research there was in chemistry and physics, not yet differentiated, was largely in the hands of the medical profession, and here again the interest centers in the city of Philadelphia, partly on account of the presence in that city of the ingenious Robert Hare; partly because of the tendencies of the University and medical school ; partly on account of the scientific traditions of the city, dating from the time of Franklin and his associates.

Many of the early contributors to 'Silliman's Journal' were physicians, with Robert Hare at their head, both in reputation and apparently in original ability. He made one addition of the first importance to the resources of the chemical investigator by his invention of the compound blowpipe, and in his two forms of voltaic cell, the 'deflagrator' and the 'calorimotor,' he foresaw dimly that fundamental law of the electric current now connected with the name of Ohm. Dr. Hare filled the chair of chemistry in the medical school of the University of Pennsylvania, and his lectures were brilliantly illustrated and of high repute.

In the history of the teaching of science, as distinguished from that of active research, the most prominent figure in the first half of the nineteenth century is not at Philadelphia, but New Haven, and its characteristics are not original power, but enthusiasm for teaching, administrative ability, social influence, sound and clear judgment.

Benjamin Silliman was graduated from Yale in 1796, with high honor and a reputation for sound scholarship. It does not appear that he had distinguished himself in scientific studies-the opportunities of specializing in that direction were not great at the Yale of that day-and he studied law after graduation from college, combining with his studies the work of a college tutor. He was admitted to the bar in 1802 . In this year a chair of chemistry and geology was established in the College and offered to young Silliman, who, at the solicitation of President Dwight, forsook the law and accepted the position.

He spent two years in fitting himself for his work, going first to Princeton, where, it is said, he first saw experiments in chemistry performed; then, after a little, to Philadelphia, remaining there till 1804. In 1805 he was abroad for nearly a year, studying and collecting apparatus and specimens. Entering upon his work, he continued in charge of his department for fifty years. His acute insight soon perceived that a pressing need of the science of the country was an organ of intercommunication, and in 1818 he founded the American Journal of Science, better known for half a century as 'Silliman's Journal.' This venture involved at first considerable pecuniary sacrifice, but became self-supporting in about four years. Its influence was very wide. In 1822 Silliman writes: "Its most extensive patronage is derived from the city of Philadelphia, which takes more copies than any other community; the cities of New York and Boston afford it about an equal and a very respectable and an increasing patronage. It is well 
sustained by Connecticut and most of the Eastern States; it is not without patronage beyond the Alleghenies, but the state of the currency has made it necessary to relinquish an extensive subscription in those regions. Washington, Baltimore, Charleston, and the Southern States generally, but especially South Carolina, demand a very considerable number of copies, and all the smaller cities receive a proportionate supply."

Already, then, the journal had assumed the representative character which it still holds, and the position of its editor among the leaders of American science was assured.

Besides his class-room and his journal, Silliman's public lectures on scientific subjects, delivered in many parts of the country, were of great value in arousing popular interest. These, like his class-room lectures, were eminently pleasing in manner and brilliantly illustrated. The courses delivered in Boston in 1840-43 first inspired the boy Josiah Cooke with an interest in chemistry which bore fruit years afterward in the sudden establishment of systematic teaching of that subject at Harvard. In his own college, of course, his influence was direct and powerful, and it was mainly his support and approval which made possible the movement toward practical chemistry at Yale. So preparations were made for the great movement of fifty years ago. At Yale the son of Professor Silliman was one of the chief actors.

Benjamin Silliman, the younger of the name, was graduated from Yale in 1837. The sailing of the Wilkes exploring expedition, carrying away James D. Dana as geologist, left vacant at once for him a place as his father's assistant, and in his father's laboratory he received the chemical training not yet available in the undergraduate courses. Impressed with the value of this practical experience, he began in 1842 to receive a few students into his laboratory, among them
J. P. Norton, afterward his assistant and colleague. This personal and private instruction was the beginning of advanced chemistry at Yale. The 'Department of Philosophy and the Arts,' under the charge of the younger Silliman as professor of chemistry applied to the arts, and Mr. J. P. Norton, fresh from two years of study at Edinburgh and Utrecht, as professor of agricultural chemistry, took possession, in 1847, of the old President's House on the College green. They paid rental to the College for use of the building, and-such was the encouragement given in those days to the teaching of science-fitted it up at their own expense and served in it without salary. "The College, indeed," says Professor Lounsbury in his "Historical Sketch of the Sheffield Scientific School, "the College, indeed, had no money to give, but, even if it had, it is more than doubtful whether it would have given it. No one at that time, however enthusiastic, ever dreamed of the supreme importance which the natural sciences soon were to assume in every welldevised system of education. The impression, indeed, seemed to prevail that chemistry, like virtue, must be its own reward."

The School, from an educational standpoint, was successful from the beginning. Norton's lamented death, in 1852, opened a place for. J. A. Porter, a pupil of Liebig, who had just resigned a similar position in Brown University. Professor Porter was a son-in-law of Joseph E. Sheffield, and to this connection was due in a great measure the expansion of these beginnings into the Sheffield Scientific School.

At Harvard, at about the same time, two streams of influence converged to swell the interest in science teaching. E. N. Horsford was called to fill the 'Rumford Professorship of the Application of Science to the Useful Arts,' in Harvard University. Horsford was a graduate of the Rensselaer Polytechnic Institute, the earliest school in 
the country to make a point of laboratory teaching. After seven years spent in teaching, surveying and geological work, under James Hall, he went abroad to study, becoming a favorite pupil of Liebig, and brought to Cambridge the methods and ideas of the Giessen laboratory.

He immediately formulated a scheme for the teaching of practical chemistry, and presented plans for a laboratory. These papers were laid by the Treasurer of the College before Abbott Lawrence, who supplied the necessary funds for this enterprise and for two other departments of geology and engineering. Agassiz was called to the chair in geology. The chemical laboratory was built in 1849, and Professor Horsford administered its affairs for sixteen years with vigor and success.

The tragedy connected with the name of Professor Webster left a vacancy in chemistry at Harvard, and in $1850 \mathrm{~J}$. P. Cooke, then only twenty-three years of age, was elected to the Erving professorship of chemistry and mineralogy. The strongest opposing candidate for this position was David A Wells, the first graduate in chemistry from the Lawrence Scientific School, since distinguished for his writings on economic subjects.

Cooke was in chemistry self-taught, with little experience as a teacher, but full of an inextinguishable enthusiasm, and an immense capacity for work. He was attracted at once to Liebig's methods, introduced by Horsford three years before. With the usual encouragement then given by college authorities in these subjects, he was permitted for the most part to provide his own apparatus and pay his own expenses, and not for seven years was his laboratory course admitted into the regular college curriculum. Even after this formal recognition a large part of the expenses of the chemical department was defrayed by Professor Cooke, and his private collection of scientific apparatus became famous and of great service to others besides himself. As lately as August, 1871, Professor Trowbridge, in describing his new cosine galvanometer, says: "My thanks are due to Professor Cooke, of Harvard College, for the generous use of his apparatus for electrical measurements ;" showing that even at that date the physical department of the College possessed no adequate collection of such instruments, but that the professors were still compelled to depend largely upon private resources.

A similar development began in 1850 at the University of Pennsylvania under James C. Booth, afterward developing into the Towne Scientific School, and at a little later date at the University of Virginia under J. Lawrence Smith. At Dartmouth College the Chandler Scientific school was founded in 1851.

At Brown University a heroic effort was made by President Wayland to enlarge the curriculum, introducing elective studies and increasing the possibility of scientific training. His notable report to the trustees, in 1850 , was in advance of the age, and although an effort was made to carry out his suggestions, and chairs were established in practical chemistry and engineering, the movement gradually waned from lack of interest and support. A scientific school was established at the University of Michigan in 1852, and a chemical laboratory built in 1856. Few other colleges appear to have felt the rising scientific wave until later.

All these scientific departments centered at first around the chemical laboratory. This is only natural, as in that science the laboratory method of teaching was first systematically developed.

The great center of practical teaching, which revolutionized the methods of the world, was Liebig's laboratory, founded at Giessen soon after his establishment there as professor, in 1826. The direct influence 
of this famous school upon Porter and Horsford has been already noted; the indirect influence, in all directions, must have been far greater.

Physical laboratories were yet unknown for some years, probably because the separation between chemistry and physics had not yet definitely taken place. The treatment of heat and electricity in the older text-books of chemistry, as agents of chemical change, tended to hold the two departments together, and in. some large institutions, as, for example, the University of Michigan, these important portions of physics were, for nearly forty years after the period we are discussing, under the control of the department of chemistry.

As laboratory teaching in chemistry is connected with Liebig, so systematic laboratory work in physics is associated with the name of Kohlrausch, whose Leitfaden, still a standard work of reference, was the first practical text-book on that subject.

Professor W. B. Rogers appears to have made the suggestion which led to the establishment of the earliest physical laboratory in this country at the Massachusetts Institute of Technology, and Professor Pickering's Physical Manipulation opened the way for the ever-increasing host of laboratory manuals in physics.

It will be seen from the above sketch that the great incentive to the founding of scientific schools in this country was the growing appreciation of the value of applied chemistry in arts and manufactures.

Of general interest in pure science, at least chemical and physical, there was little or none; but the recognition of the value of applied science led, within a few years, to the great company of technical and engineering schools which have been, until very lately, the most imposing feature in our American system of higher education.

First among these, by many years, was the Rensselaer Polytechnic Institute, of
Troy, New York, the early history of which merits some attention. It was founded in 1824, by Stephen Van Rensselaer, and practically placed under the charge of his protégé, Amos Eaton. The purpose of the school was defined by the founder to be the instruction of 'persons who may choose to apply themselves in the applications of science to the common purposes of life.' "My principal object," he adds, " is to qualify teachers for instructing the sons and daughters of farmers and mechanics, by lectures or otherwisé, in the applications of experimental chemistry, philosophy and natural history to agriculture, domestic economy, the arts and manufactures."

Professor Eaton gave to this philanthropic idea a turn of great originality and value. Since he was to educate chiefly lecturers, they should learn to lecture at the school. Since they were to lecture on the applications of science, they should themselves become practical manipulators. The work, therefore, of the classes consisted largely " of experiments in chemistry, performed by themselves, and in giving explanations, or the rationale of the experiments * * *; the students thus themselves acting as lecturers, and the professors as students." Laboratory methods, in fact, were used throughout, and the school was equipped, so far as possible, with this idea in view. Doubtless the work was not so well systematized as in Liebig's laboratory, opened several years later, but it was an original and independent movement in the same direction, and that it was efficient may be inferred from the number of wellknown men of science who were graduates of this school. Slowly, in response to popular demand, the Rensselaer Institute turned more and more toward engineering, and it is a curious fact that the very epoch which beheld other institutions broadening their scientific courses saw this one, in the reorganization of 1849-50, contracting its field- 
practically to that of a school for civil engineers.

Of the great number of technical schools which have sprung up since 1850 there is no need to speak. But the interest in science has gradually passed far beyond the mere interest in its applications.

The striking features of the last twenty years have been the spread of science teaching by laboratory methods in the secondary schools, and the growth of university instruction in science, as distinguished from technical. The noble gift of Johns Hopkins, and its wise administration, began the latter movement, which resulted in the establishment of graduate schools all over the country. The State universities, with their large resources, were, in some parts of the land, great aids in this work, though in others they kept more closely in touch with the technical side, as is very natural with institutions supported by the public at large.

The growing fashion among students, of completing their years of study in Germany, has had a most important effect. The instructors in science in our colleges are drawn more and more from those who have added German training to that of their native country, and as a result the ideals in these institutions are approximating to the German ideals.

Ability in the direction of original research is in some places the first quality looked for in a student or required of an instructor, and the modern tendencies toward extreme specialization and hasty publication are natural results.

So far the movement has undoubtedly been productive of good to the whole educational system of this country. There has been an arousing, an awakening, in educational ideas and methods, not in science only, but in all other subjects, that is little less than marvellous to him who can look back five and twenty years. Whether, after our American fashion, the pendulum may swing too far, and the movement bring with it the difficulties which always attend exaggerations, it is too early yet to say, but, so far as we have gone at present, not only teachers of science, but all teachers, may join, in spirit at least, with the meeting at Boston, which really celebrates the beginnings, not merely of a scientific association, but of a great scientific and educational movement, of which the Association forms but a part.

Frank P. Whitman.

\section{HYDRAULIC ILLUSTRATION OF THE WHEATESTONE BRIDGE.}

Although it is undesirable to push the analogy between the electric current and the flow of water too far, or to get the idea of an actual current too firmly established in the student's mind, still a hydraulic illustration is often useful to point out how the results may follow.

To show the action of the Wheatestone bridge by flowing water is usually complicated by the effects of gravity, and illustrates the conditions of pressure rather than those of resistance to flow. Moreover, the question of the galvanometer is a troublesome one, inasmuch as most devices require such a flow of water as to interfere with the bridge effects which it is desired to bring out.

The arrangement described below has proved quite satisfactory in showing the simpler resistance effects in the bridge, but especially useful in making clear the effects of capacity and self-induction, and how the two may be balanced and compared.

The accompanying sketch is taken from a simple home-made bridge which was constructed as an experiment. Upon a board about $30 \times 50 \times 4 \mathrm{~cm}$. are fastened four glass $T$ 's of about $5 \mathrm{~mm}$. inside diameter. Two of these $T$ 's have their side projections 